\title{
Business Models Innovation through New Customer Roles: A Design-Driven Case Study
}

\author{
Marco Pironti*, Cabirio Cautela**, \\ Joannis Christodoulou***
}

\begin{abstract}
Business models as relational devices governing transactions with the customers and stakeholders identify new rules of customer engagement and their impact on business model innovations in design-intensive industries. These industries, framed as the locus of 'cultural innovation', see the customer as a product 'sense giver'. In this setting, new customer roles are explored through a case study based on a fast-growing company operating in the furniture sector.

The case study highlights three main customer roles that impact business models: (i) the customer as a market bridge; (ii) the customer context as a company 'showroom'; (iii) the customer as an external company design lab.
\end{abstract}

Keywords: Product Design; Business Models Innovation; Customer Engagement; Design-Intensive Industries; Global Strategy

\section{Business Models Innovation In Design-Intensive Industries}

Business model innovation is gathering a growing attention in design and management field (Martin 2009; Osterwalder, Pigneur 2010; Battistella al. 2012). In different industrial context the seeking for a new business model disrupted the competitive rules and the sources of value. Cases as Hilti, Groupon, Patientlikeme, are recognized as representative of disruptive business model innovation (Markides 2006) leveraging on a wise integration between on and off line activities and on new customer engagement roles.

A significant literature centered on business model innovation relates to web companies and e-business (Timmers 1998). Mainly start-ups and new ventures are considered as the main players that introduced new business models and logics with the evolutionary waves of the digital economy.

On the other hand business models innovation are becoming source of value also in industries where the technology innovation and the pace of it are not relevant.

\footnotetext{
*Associate Professor of Management, University of Turin (marco.pironti@unito.it)

** Associate Professor of Management and Strategic Design, Politecnico of Milan (cabirio.cautela@polimi.it)

*** Senior Lecturer in Business Strategy, Westminster University

(i.christodoulou@westminster.ac.uk)
}

Edited by: ISTEI - University of Milan-Bicocca

ISSN: $1593-0319$

Pironti Marco, Cautela Cabirio, Christodoulou Joannis (2015) Business Models Innovation through New Customer Roles: A Design-Driven Case Study, Symphonya. Emerging Issues in Management (symphonya.unimib.it), n. 2, pp. $25-41$.

http://dx.doi.org/10.4468/2015.2.03 pironti.cautela.christodoulou 
Nevertheless the scientific debate about business model innovation in designintensive industries - as fashion, furniture, accessories, interiors, textile - where the innovation process is driven by the proposition of new product meanings and languages (Verganti 2009) and cultural messages (Ravasi al. 2012) seems to be poor.

Framing business model as a 'relational device' the paper aims to identify business model innovation logics in design driven contexts where the relationship between product innovation and business model innovation seem to be relevant and fertile (Battistella et al. 2012).

To accomplish this aim, a case study based on explorative research has been conducted. The company for study was selected because it met the following three criteria: (i) had a widely acknowledged innovative business model; (ii) operates in design intensive industry where the content of innovation is based on new cultural messages and meaning conveyed by the product; (iii) generates new forms of customer relationship through new engagement roles.

\section{Theoretical Background And Research Questions}

As can be expected by delineating the meaning of the business model in the web economy, the concepts of flow and relationship are significantly stressed. A business model represents the device by which the main flows and the company's web of relationships are designed, aiming to create benefits for the different participating actors, as providers, partners, customers (Brondoni 2005; Amit, Zott 2001).

In their attempt to extend the business model concept by trying to go beyond the foundation originally centered in e-business, Amit and Zott (2001) define the business model as 'the content, structure, and governance of transactions designed to create value through the exploitation of business opportunities.'

Even in this case, through the term transaction, scholars pinpoint the relational rationale underpinning how in the business model concept the exchange and interactive dynamics prevail.

On the other hand recalling the basic business question advanced by Drucker, Magretta (2002) describes business models as

Stories that explain how enterprises work. A good business model answers Peter Drucker's age-old questions: Who is the customer? And what does the customer value? How do we make money in this business? What is the underlying economic logic that explains how we can deliver value to customers at an appropriate cost?(Magretta 2002)

Here, the concept of the customer, customer value and money making are intended to be constitutive business model elements.

Other scholars have grappled with the attempt to split a business model and to identify its various components.

According to Osterwalder, Pigneur and Tucci (2005), 
$\square$ A business model is a conceptual tool containing a set of objects, concepts and their relationships with the objective to express the business logic of a specific firm. Therefore we must consider which concepts and relationships allow a simplified description and representation of what value is provided to customers, how this is performed and with which financial consequences. (Osterwalder et al. 2005)

In an initial proposal, these authors identify four main pillars - the product, the customer interface, the infrastructure management and the financial aspects around which some 'building blocks' are identified.

In a later release, Osterwalder and Pigneur (2010) directly proposed a 'nine building blocks business canvas' (i.e., value proposition, channels, customer relationships, customer segments, revenue streams, key activities, key resources, key partnership, cost structure).

Other scholars have provided a more compact version. Specifically, business model based on six elements has been depicted where value proposition, customers, internal processes/competencies, external positioning, the economic model and personal investor factors constitute the key elements of the model (Morris, Schindehutte, Allen 2005).

Voelpel, Leibold and Streb (2005) mention three basic components of a BM: value proposition for customers, value network configuration to create that value, and returns ensuring the satisfaction of relevant stakeholders and, thus, the sustainability of the business model.

On the other hand, a business model concept based on four characteristic elements (customer value proposition, profit formula, key resources, and key processes) has been defined (Johnson, Christensen, Kagermann 2008), pointing out the interlocking logic among the different elements.

Table 1: Literature Review

\begin{tabular}{|l|l|}
\hline Authors & Focus on \\
\hline Timmers (1998) & $\begin{array}{l}\text { Product, service and information flows, } \\
\text { business actors }\end{array}$ \\
\hline Weil and Vitale (2001) & $\begin{array}{l}\text { Roles and relationships among a firm's } \\
\text { consumers customers, allies, and } \\
\text { suppliers }\end{array}$ \\
\hline Amit and Zott (2001) & Transactions \\
\hline Magretta (2002) & $\begin{array}{l}\text { Customer value, economic logic, value } \\
\text { delivery }\end{array}$ \\
\hline Morris et al. (2005) & $\begin{array}{l}\text { Value proposition, customer, internal } \\
\text { processes/competencies, external } \\
\text { positioning, economic model and personal } \\
\text { investor factors }\end{array}$ \\
\hline Osterwalder, Pigneur and Tucci (2005) & $\begin{array}{l}\text { Product, customer interface, the } \\
\text { infrastructure management and the } \\
\text { financial aspects }\end{array}$ \\
\hline
\end{tabular}




\begin{tabular}{|l|l|}
\hline Voelpel et al. (2005) & Value proposition, value network, returns \\
\hline Johnson et al. (2008) & $\begin{array}{l}\text { customer value proposition, profit } \\
\text { formula, key resources, and key processes }\end{array}$ \\
\hline Osterwalder and Pigneur (2010) & $\begin{array}{l}\text { value proposition, channels, customer } \\
\text { relationships, customer segments, revenue } \\
\text { streams, key activities, key resources, key } \\
\text { partnership, cost structure }\end{array}$ \\
\hline
\end{tabular}

In any case, the different attempts to identify the components, the transactional and relational dimensions of the business model are depicted as fundamental. The concepts of 'customer value proposition', 'customer value', 'customer segments', 'key partnership', and 'customer relationship' point out the interactive and relational dimensions of the core of the business model.

If there is a common consensus about the basic components of business model as a construct there are heterogeneous perspectives about the way to conceive and interpret the business model innovation.

A primary research strand emphasized how business model innovation is induced by or mainly related to technological innovation.

As stated by Teece (2009), 'technological innovation often needs to be matched with business model innovation if the innovator is to capture value.'

Furthermore, new business models have been usually connected to new R\&D strategies. In "Open Business Models", Chesbrough (2006) affirms:

\section{$\square$ An open business model uses the new division of innovation labor- both in the creation of value and in the capture of a portion of that value. Open models create value by leveraging many more ideas, due to their inclusion of a variety of external concepts. Open models can also enable greater value capture, by using a key asset, resource, or position not only in the company's own business but also in other companies' businesses. (Chesbrough 2006)}

The author, going beyond the vertical integrated company concept in which the R\&D exploration and exploitation are equally run, identifies two ways to build open business models: (i) the inside-out approach, where ideas, patents and copyrights are internally produced and then licensed to external actors that take them on the market; (ii) the outside-in approach, where companies grasp ideas and technologies from external networks turning them into products to commercialize on the marketplace (Chesbrough 2006).

Both approaches tend to stress 'openness' as a dominant way to innovate business models in a successful and profitable manner.

In contrast, Johnson et al. (2008) citing real successful cases as Hilti, Intuit, and Apple as cases propose the soul of business model innovation in 'keeping people from getting particular jobs completed: insufficient wealth, access, skill or time.'

In a similar vein another research strand relates business model innovation to the way goods and services are purchased and accessed by the customer.

Firstly, Markides (2006), claiming for the 'need of a better theory,' emphasizes the difference between disruptive innovations and business model innovations, 
pinpointing how the latter tend to basically change competitive rules of a sector and 'enlarge the existing economic pie,' either by attracting new customers into the market or by encouraging existing customers to consume more. Furthermore, according to the author, ' $(\ldots)$ it is important to note that business model innovators do not discover new products or services; they simply redefine what an existing product or service is and how it is provided to the customer.'

Consistent with this approach and centering on the transaction dimension, Zott and Amit (2008) also interpret business models innovation as new forms of economic exchanges. According to the authors:

$\square$ Novelty-centered business models refer to new ways of conducting economic exchanges among various participants. The conceptualization and adoption of new ways of conducting transactions can be achieved, for example, by connecting previously unconnected parties, by linking transaction participants in new ways, or by designing new transaction mechanisms. (Zott, Amit 2008)

The vision that business model innovation occurs when changes are made in the way to conduct transactions, to create and deliver value and to build up new customer relationships is indeed widely accepted.

Mainly in service sectors and in the fast-paced technology industry, different business model innovations have been conceived, reconfiguring the customer's role in the production process.

The dominant innovation directions that have been pursued involve the customer's role as a collaborative producer (McKelvey 2001; Brondoni 2011; Pisano, Verganti 2008; Johnson et al. 2008). The advent of a user-generated content movement, the diffusion of social media and Web 2.0 technologies, and the emergence of skilled and well-educated customers have enabled whole crowds or single users to heavily collaborate in the production processes of companies. According to this framework, the customer is a company production or codeveloping partner that jointly affects the evolution, the costs and the benefits of the value system.

With Apple, iPhone users are free to conceive and hopefully sell their own apps; in the Linux operating system, people take part in writing codes and strings to optimize the functionalities and the performance of the system; with different lowcost airlines, customers are empowered to accomplish check-in activities and most of the luggage handling on their own.

The entire literature aligned to this frame is usually contextualized in the fastpaced technology industry or in service industry (Mohanbir, et al. 2005; Von Hippel 2005; Grocott, et al. 2007; Shneiderman 2007). Specifically this literature seems to avoid the relevant distinction between the cases where the customer plays the role of a mere product assembler - thus customizing the final offering - and the cases where the user represents an operative gear of the business model or even a provider of stimuli for business model change.

In design-intensive industries, where the competitive dynamics are driven by a continuous proposition of new product languages and meanings (Brondoni 2012, 
Verganti 2003; 2008; 2009), there is a wide lack of literature about the business model innovation.

In design-intensive industries, products are more or less open narratives in which customers are involved in defining the product sense and meaning (Krippendorf 1989; Norman 2005; Verganti 2003; 2009; Searls 2009). Thus the customer does not play the ordinary role of receiver but acts sometimes as 'sense giver', some others as a co-designer, till to be a full 'maker'.

Moreover the creation of product meaning seems not to be delegated to the tangible product in itself, but to the entire business model that companies run and to the ways in which customers are engaged in it (Battistella, Biotto, De Toni 2012).

Notwithstanding, some questions remain open and fertile to reach a deeper understanding of how companies create business model innovation by leveraging new customer roles.

What are the customer engagement strategies to change the business model in design-driven companies? Are there specific roles that appear as proper of those design intensive contexts?

Due to a lack of previous literature, these research questions are addressed in this paper through the development of an explorative case study analysis.

\section{Research Strategy}

Literature about business model innovation is basically centered on fast-paced technology industries. Furthermore, if design-driven innovation is a concept that has widely permeated the management literature (Dumas, Mintzberg 1989; Verganti 2003; 2006; 2009; Noble, Kumar 2010; Ravasi, Lojacono 2005; Ravasi, Stigliani 2012), there is a neglected area of research where design management studies meet business dynamics and becomes relevant to innovate the business model as a whole.

This literature scarcity led to explorative research based on a case study analysis (Eisenhardt 1989; Yin 1981; 1984; Mintzberg 1979). According to the words employed by Eisenhardt (1989):

There are times when little is known about a phenomenon, current perspectives seem inadequate because they have little empirical substantiation (...). In these situations, theory building from case study research is particularly appropriate (...). (Eisenhardt 1989)

The first methodological issue faced by the research group pertained to the criteria through which to select a particular case study. A primary sample of 25 Italian furniture companies was considered. The sector choice was indicated as a representative field of design-intensive industries where companies mostly compete on the proposition of new product languages and meanings (Dell'Era, Verganti 2007; 2011) and on cultural innovation (Ravasi et al. 2012).

The sample companies were identified by matching two different criteria: (i) the turnover growth rate in the previous 4 years; (ii) the introduction of novel features in business model. 
The first quantitative parameter helped to select an initial ranking of ten companies. The final selection of the case to investigate was run according to an open discussion about the concept of 'innovativeness of the business model'. This concept was discussed in a research group of 5 scholars of Politecnico di Milano and University of Torino (2 Assistant Professors in the Design area; 2 Associate Professors in the Innovation Management area; 1 Full Professor in the Business Innovation area).

The concept of innovativeness was split according to two main dimensions: (i) the depth of the innovation, intended to indicate how much the transactions flows and the company-customer relationship changed in business models; (ii) the breadth of the innovation, intended to indicate how many components of the business model have been affected by change with respect to the traditional sectorial trends.

The selection indicated LAGO as the most representative case of business model innovation, where both the levels of depth and breadth of innovation were agreed to by the members of the research group.

As required by theory building based on case study, a combination of multiple sources and investigation methodologies was exploited to achieve a certain robustness and extensibility of the results (Yin 1981; Eisenhardt 1989).

The case study analysis was conducted over a period of one year and 5 months, involving three main sources in an iterative way:

- a press analysis conducted on 26 journals and design-related magazines in the time range 2009-2013;

- five in-depth interviews, three of which were conducted with the LAGO CEO, Daniele LAGO, and two were conducted with an external consultant architect, Massimo Antinarelli;

- participation in four workshops and events organized by the Brera LAGO Apartment, located in Milan.

The press analysis supported a primary understanding of the LAGO business system. Different articles (18 of 26 articles) emphasized both directions of innovation pursued by the company: innovation in the product and in the customer relationship, product exhibition and distributive chain. A great amount of attention (15 on 26 articles) and space has been dedicated by the press to the 'LAGO Apartment network' and its novel ways of engaging customers and building new relationships.

These initial understandings derived by the press analysis supported the formulation of the main issues and questions that were explored in the subsequent interviews.

Interviews focused on the following aspects:

- driving forces that supported innovation in the business model;

- innovative concepts related to the LAGO business model;

- product design strategies and creativity management;

- logics to engage and manage relationships with customers;

- distributive policies and the LAGO Apartment network. 
Following these interviews, researchers' participation in four workshops and events organized by LAGO was encouraged to experience and grasp the atmosphere and the social interaction among the different involved actors.

Different assessments were taken, aiming to identify qualitative customer profiles, the type of events held and how customers are involved in relevant activities (workshops, events, artistic performances, etc.).

Figure 1: Iterative Research Process

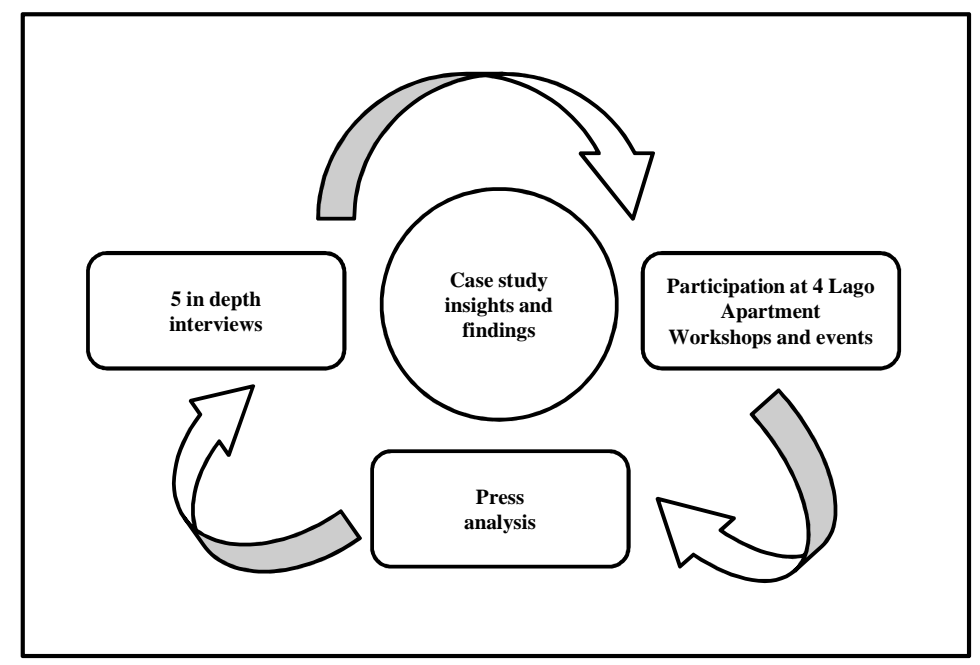

Three data sources have been employed in an iterative way. Primarily, a first cluster of articles (15) were read to grasp an overall understanding about LAGO's innovation and design strategy and its underpinning business model. The main concepts derived by reading the articles supported the formulation of an openanswer questionnaire submitted to LAGO's CEO and architect consultant (2 initial interviews). The questionnaires supported the first development of theoretical constructs and some main hypothesis about the form and the logic of the business model and the company's logic of customer engagement. Following the administration of these questionnaires, the researchers' participation in three main events and workshops organized by LAGO Apartment helped to qualify a direct experience with the concepts and findings related to the tenants' and participants' experience.

A second iterative flow, mainly focused on additional articles, readings, and three more interviews, supported the refinement of the proposed concepts, and a final confirmation of findings and main concepts were derived by the last interview. In this paper, only a brief essay is presented to highlight the focal points related to LAGO's product design strategy, business model, logic, and pattern of customer engagement. 


\section{Case study: LAGO}

LAGO was founded at the end of the nineteenth century by Policarpo Lago, a wood craftsman who worked in aristocratic homes and Venetian churches. The generation that followed continued his tradition, but expanded their production first to bedroom furniture and later to entryway furniture. Today, LAGO is considered a fast-growing company in the italian furniture landscape, where it grew from approximately 5 million $€$ of turnover in the first two years of the company's redesign to 30 million $€$ of turnover in 2010, with approximately 170 employees (of which over $25 \%$ were hired in 2008).

LAGO can be found in 400 selected shops around the world and has numerous directly managed stores in several Italian and European cities, including Rome, Milan, London, Paris and Barcelona. Lately, the company began some fertile ventures with partner leaders in different sectors to enlarge their range of products and share the pursuit of people-friendly designs, thus creating solutions that can improve the customer's quality of life.

Recently, the company has opened itself to the skills of craftspeople and designers to retrieve the importance of handwork ability, local embedded knowhow, and care for detail. This was the beginning of the 'LAGO Objects' collection, a set of small objects of high quality and craftsmanship.

The entire LAGO business model is based on two main pillars:

- an innovative product design strategy, fostered by the LAGO STUDIO, the creative hub where young, external and talented designers are engaged to conceive new product propositions;

- an innovative customer engagement model, based on the creation of a diffused network of LAGO APARTMENT, where LAGO-furnished apartments of specific customers operate as showrooms and productdiffusing vehicles.

\section{Managing product design at LAGO}

At LAGO, products are conceived as parts of an alphabet. Each product combined with other parts can assume a proper aesthetic language and style. The combination of the product language is delegated to the hands of the customer. Products are conceived as an open or unfinished work, a sort of open narrative that assumes sense on the basis of the successive 'reader' interpretation (Eco 1989). The products' modularity and their openness and flexibility to be adapted to different contexts permit a full re-interpretation by the customer-reader (Figure 2). 
Figure 2: Slide Carpet by LAGO

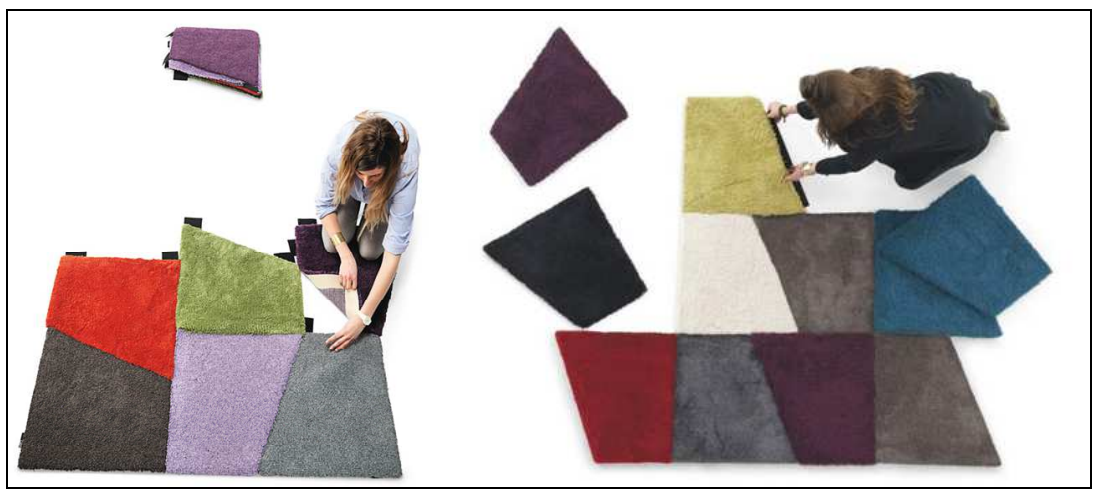

The other feature of the design strategy consists of conceiving product systems. Going beyond the logic of the single product as protagonist in a specific context (as the typical design masterpieces designed by the internationally recognized designers), LAGO proposes products to be aggregated in a way to suggest a proper whole language, a coherent and organic mood of living and domesticity. Products are conceived as a part of systematic offering where each one relates to others in terms of color, shape, texture, and sense. LAGO offers a sort of language bundle more than independently designed products.

Practically, this means that the company considers the space as an organic system in which furniture products communicate with each other. At LAGO, design means creating small designs (products) and, at the same time, knowing how to create large designs (design systems) by looking at the home and its habitability as a whole.

The creation and the design of new product platforms and languages is partially internal and partially entrusted to an external creative hub: the LAGO Studio. LAGO Studio is the company's temporary environment in which different cultures and geographically dispersed people meet to generate new concepts and products.

In fact, LAGO organizes a yearly creative workshop, hosting young university students and designers from around the world and schools such as Saint Martin's, London Royal College of Art, Eindhoven Design Academy, and Milano Domus Academy. The main logic behind these workshops consists of engaging young and inexperienced designers to dive into LAGO's philosophy and to contribute to developing new design systems and single products.

\section{Innovating Business model exploring new customer roles}

What about the customer? Far from the 'production function' highlighted in fastpaced technology industries, where the customer plays the role of a collaborative producer, at LAGO, customers are engaged according to other logics and functions.

First, the customer seems to act as a market bridge for the company. The tenants of the LAGO Apartment network form an 'inner circle' aiming to access different market segments (Figure 3). Leveraging their own relationships or directly supported by LAGO in multiplying contacts and meeting opportunities, the tenants represent a contact gate where to experience a real LAGO Apartment with a proper mood, language frame, aesthetics, living space and organization. 
In cases where the tenant is also an architect or a designer, the value of the relationship is even more evident. The professional tenant interested in enlarging his customer base and work opportunities can leverage being at the center of an open network that naturally attracts customers interested in design and architecture.

Figure 3: The LAGO Apartment Network as Market Bridge

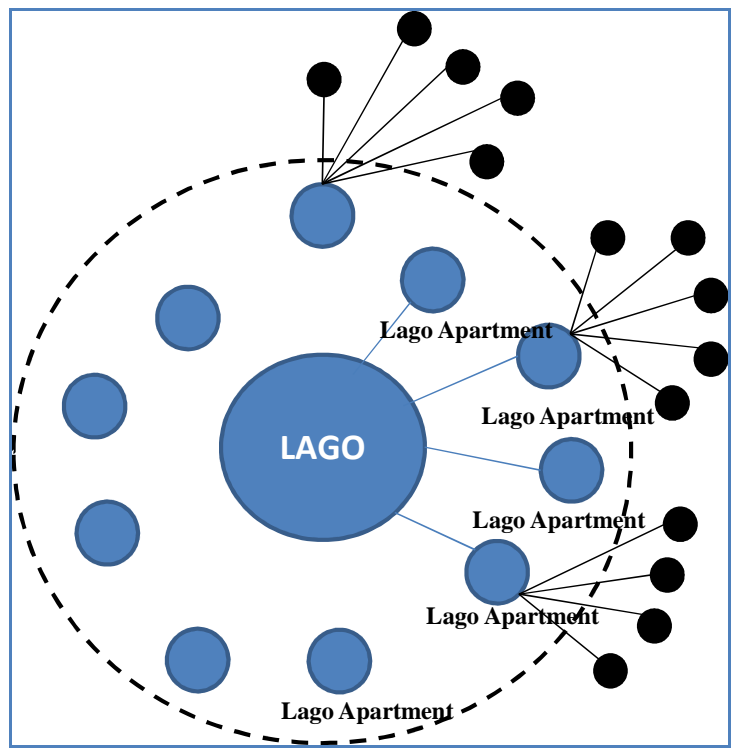

On a second hand the Lago Apartment constitutes a network of unconventional show-rooms, such as exhibition platforms really lived by the customers-tenants.

The fact that these apartments are real houses or offices of customers provide a more familiar atmosphere for visitors and prospects, thus decreasing the formality, the rigidity and the commercial protocols that used coupled with the typical show rooms. The informal atmosphere and the acknowledgment to be welcomed in a lived house enable more sincere and fertile relationships and the possibility to freely appreciate or not the whole aesthetics and the single items.

Thirdly, tenants can be considered as innovation promoters. As matter of fact when customers submit their project proposals to enter and take part in the LAGO Apartment network, they provide new and inspiring knowledge for innovation. They do so by proposing completely fresh product combinations and languages or by radically proposing new LAGO aesthetics and settings by reinterpreting existing product languages and meanings. LAGO Apartments, according to this role, can be depicted as extended 'design laboratories' oriented towards grasping innovative signals and generating fresh insights (Dell'Era, Verganti 2009).

These roles directly impact the LAGO business model.

Being a market bridge, customer impacts on the market making function affecting on the company revenues. When they open their house to show their furniture to their contacts and to additional potential customers they are creating the customer experience that is expected to affect the purchasing dynamics and thus the revenue flows. 
In the same vein providing the customer houses in exhibition and show rooms affects the cost structure decreasing the exhibition and retailing costs.

Lastly the role played by customer more than feeding the actual business model provides inspirational knowledge to foster innovative products and systems.

Table 2: The three Roles played by the Customer in Lago Business Model

\begin{tabular}{|l|l|l|}
\hline Customer as & Function & Direct impact on \\
\hline $\begin{array}{l}\text { Market bridge/Commercial } \\
\text { partner }\end{array}$ & $\begin{array}{l}\text { Connection with } \\
\text { potential users }\end{array}$ & $\begin{array}{l}\text { Market } \\
\text { enlargement/New } \\
\text { revenues }\end{array}$ \\
\hline Showroom & $\begin{array}{l}\text { Product placement, } \\
\text { 'living' exhibition }\end{array}$ & $\begin{array}{l}\text { Reduction of } \\
\text { communication and } \\
\text { exhibition costs }\end{array}$ \\
\hline Design innovation promoter & $\begin{array}{l}\text { Exploration of new } \\
\text { design patterns and } \\
\text { product languages }\end{array}$ & $\begin{array}{l}\text { Innovation trajectories } \\
\text { Inspiring knowledge } \\
\text { base }\end{array}$ \\
\hline
\end{tabular}

\section{Discussion}

The presented LAGO case study evidences at least three key issues in business model innovation.

First, for long time, business models and innovation have been considered as two different aspects pertaining to the company's management. Business models as related to 'value creation and capture' have been analyzed as operational devices mostly pertaining to the company operating routine. Contrarily, innovation has been framed as a changing activity oriented to move company assets, strategy and value creation means towards thriving and superior performance levels. In other words, a business model relates to exploitation, whereas innovation equals exploration (March 1991).

This clear-cut separation seems to lose its validity. As evidenced by LAGO, the business model and innovation are intertwined concepts. LAGO innovatively created its own business model, changing the typical value drivers in the furniture industry and at the same time, its business model fosters continuous innovation because some of its constituent elements - i.e., the LAGO apartment network feed stimuli and insights to the company about sociocultural models and new emerging patterns in terms of product languages and meanings.

The business model in LAGO's case not only guarantees value creation and its 'appropriability'. but it also works as an engine aiming to update and revamp product languages and meanings.

The intertwined relationship between the business model and innovation activities proposes different questions about the locus and the management of R\&D. At LAGO, R\&D is spread out into three main moments and entities: LAGO Studio is the creative platform in which foreign and other talented designers seek for new concepts and products languages; the LAGO Apartment network feeds stimuli and insights handled and systematized to build design briefs and inspirational 
knowledge for LAGO Studio designers; the internal department solves technical issues and drives concepts towards the manufacturing process.

More than an open innovation pattern (Chesbrough 2006), the LAGO business model enables a diffused $R \& D$ and design activity system in which the LAGO apartments play the role of explorative and diffused design labs, feeding cultural insights, product languages and inspirational apartment language moods.

A second finding that emerged from the case study deals with the scope and 'object' of design-driven innovation. Design-driven innovation has traditionally related to the product scope (Verganti 2003; 2009; Noble, Kumar 2010). Product meaning and language change has been framed by scholars as a change of some tangible product elements such as shape, material, texture, color, joining relationships, and finishing (Dell'Era, Verganti 2007; Person et al. 2008; Ravasi, Stigliani 2012; Noble, Kumar 2010).

In LAGO, however, design has been applied to the entire value system and business model. Design is progressively being employed to innovate services, intangibles, applications, and interfaces (Morelli 2002; Manzini, Vezzoli 2003; Brown 2008). The dematerialization of offerings is driving companies and designers to enlarge the design scope range from a product and tangible dimension to the overall value system, where business models take up a prominent role (Osterwalder, Pigneur 2010). This point seems to strengthen the literature strand at the intersection between design and management studies labeled 'design thinking' (Brown 2008; Dorst 2011; Martin 2009), where creativity and lateral thinking, with a proper mindset, knowledge and cognitive tools, foster the organizational innovation.

A third piece of evidence linked to this second point addresses the specific direction of business model innovation. LAGO introduced a novel business model in the furniture industry, reconfiguring the customer relationship system and the logic of customer engagement.

In a sector such as furniture, where fragmented and small distributive players or large low-cost malls prevail, LAGO revamps the customer relationship by introducing a familiar concept - the apartment - and provides the customer with three novel roles and functions.

These new roles and functions identify the customer as a key asset in creating the LAGO business model and in boosting and stimulating the innovation process.

Recalling some new productive roles attributed to customers in fast-paced technology industries, business model innovation through the alteration of company relational systems is becoming a critical outpost in innovation management studies and practice.

Assuming a more general perspective, business model innovation through the alteration of the company relational system can be framed according to main variables or 'objects to change': the actors and their roles.

According to this framework, business model innovation can be fostered by:

- changing the actors, when new actors (customers or stakeholders) are included in business models as providers of new assets or activities;

- changing the roles of actors, when the same or new actors are provided with novel roles in the value creation process. 
The proposition of this theoretical frame tries to enlarge the perspective of business model innovation as mostly depicted in fast-paced technology industries where a robust research strand provides a dominant view in which business model innovation is mainly based on 'openness' and on a collaborative production function exerted by the customer. Based on a case study methodology approach, the proposed framework aims to enlarge the range of study of business model innovations towards other industrial settings and competitive environments to deepen existing knowledge and seek new findings.

In the conclusion below, the limits of this research are highlighted and some possible new research directions are proposed.

\section{Conclusions}

Business model innovation has undergone deep changes due to the different ways to engage $R \& D$ partners, technology providers and customers in the company value system. Innovating business models through opening them to a wider group of stakeholders has become more than a fad. Consolidated literature in the fast-paced technology industry focused on the different ways to engage external partners as co-developers or collaborative producers.

Design intensive industries, where companies compete through the creation and the diffusion of new product languages, symbolic values and cultural messages have been traditionally neglected, leaving a research gap in understanding other additional business model innovation trajectories where products are framed as 'open narrations' and the customer is a 'sense giver' more than user enticed by product functionalities and performance.

The analysis of LAGO as a case study notes how the customer is basically a key asset of LAGO's business model. LAGO's case shows how customers can assume roles different from those of co-developers or collaborative producers.

LAGO pinpoints how business model innovation can be fostered by engaging customers with new roles and logics. At LAGO, the customer acts as the company's market bridge, forming an 'inner circle' that enables the company to access different market segments. The apartment of the tenant-customer furthermore acts as an exhibition platform where events and workshops are organized to host potential customers in a sort of 'living showroom'. Additionally, customers, by submitting their 'apartment ideas' to the company, provide their own perspectives and aesthetics for LAGO apartments, acting as an external design lab and innovation promoters.

These highlighted customer engagement tools mainly show how other business model innovation trajectories are pursued in industries that are different from the logic pursued by the fast-paced technology industry.

The limits of the demonstrated insights and findings are related to the development of a single case study.

However, several signals by which to interpret other ways to innovate business models according to new customer engagement rules cannot be neglected.

As outlined in the LAGO study, new directions of business model innovation are even aligned with new R\&D management systems. LAGO apartments become 
external platforms, design labs or antennas through which part of the R\&D process is managed by a community of architects, designers, and customers.

The outcome of these design labs is a sort of inspirational knowledge that feeds the LAGO Studio creative hub and internal technical offices.

Future research can deepen the knowledge surrounding new roles and functions of the customer in innovative companies' business models. A further investigation could strengthen the presented insights by exploiting a quantitative analysis on a wider case sample.

Moreover, extending the research questions and the framework of this study to other fast-paced design industries, e.g., the fashion industry, where the evolution of product language and meanings is particularly rapid, could provide additional findings about the logic of customer engagement in business model innovations.

Furthermore, the rapid emergence of fashion and the changing role of distribution within the fashion industry could provide additional rules for customer engagement and rich new insights about relationship-based business model innovations.

\section{Bibliography}

Amit Raphael, Zott Christoph (2001) Value Creation in e-Business, Strategic Management Journal, vol. 22, n. 6-7, pp. 493-520. http://dx.doi.org/10.1002/smj.187

Battistella Cinzia, Biotto Gianluca, De Toni Alberto F. (2012) From Design Driven Innovation to Meaning Strategy, Management Decision, vol. 50, n. 4, pp. 718-743. http://dx.doi.org/10.1108/00251741211220390

Brondoni, Silvio M. (2012). Innovation and Imitation: Corporate Strategies for Global Competition. Symphonya. Emerging Issues in Management (symphonya.unimib.it), 1, 10-24. http://dx.doi.org/10.4468/2012.1.02brondoni

Brondoni, Silvio M. (2011). Global Networks, Knowledge Management and World Cities. Symphonya. Emerging Issues in Management (symphonya.unimib.it), 1, 7-18.

http://dx.doi.org/10.4468/2011.1.02brondoni

Brondoni Silvio M. (2005) Managerial Economics and Global Competition, Symphonya. Emerging Issues in Management (symphonya.unimib.it), n. 1, pp. 14-38. http://dx.doi.org/10.4468/2005.1.02brondoni

Brown Tim (2008) Design Thinking, Harvard Business Review, vol. 86, n. 6, pp. 84-92.

Chesbrough Henry W. (2006) Open Business Models: How to Thrive in the New Innovation Landscape, Harvard Business School Press, Boston.

Dell'Era Claudio, Verganti Roberto (2011) Diffusion Processes of Product Meanings in Design-Intensive Industries: Determinants and Dynamics, Journal of Product Innovation Management, vol. 28, n. 6, pp. 881-895.

http://dx.doi.org/10.1111/j.1540-5885.2011.00849.x

Dell'Era Claudio, Verganti Roberto (2009) Design-Driven Laboratories: Organization and Strategy of Laboratories Specialized in The Development of Radical Design-Driven Innovations, $R \& D$ Management, vol. 39, n. 1, pp. 1-20. http://dx.doi.org/10.1111/j.1467-9310.2008.00541.x

Dell'Era Claudio, Verganti Roberto (2007) Strategies of Innovation and Imitation of Product Languages, Journal of Product Innovation Management, vol. 24, n. 6, pp. 580-599. http://dx.doi.org/10.1111/j.1540-5885.2007.00273.x

Dorst Kees (2011) The Core of 'Design Thinking' and Its Application, Design Studies, vol. 32, n. 6, pp. 521-532.

http://dx.doi.org/10.1016/j.destud.2011.07.006 
Dumas Angela, Mintzberg Henry (1989) Managing Design: Designing Management, Design Management Journal, vol. 1, n. 1, pp. 37-43. http://dx.doi.org/10.1111/j.1948-7169.1989.tb00519.x

Eco Umberto (1989) The Open Work, Harvard University Press, Cambridge.

Eisenhardt Kathleen M. (1989) Building Theories from Case Study Research, Academy of Management Review, vol. 14, n. 4, pp. 532-550. http://dx.doi.org/10.2307/258557

Grocott Patricia, Heather Weir, Mala Bridgelal Ram (2007) A Model of User Engagement in Medical Device Development, International Journal of Health Care Quality Assurance, vol. 20, n. 6, pp. 484-493. http://dx.doi.org/10.1108/09526860710819422

Johnson Mark W., Christensen Clayton M., Kagermann Henning (2008) Reinventing your Business Model, Harvard Business Review, vol. 86, n. 12, pp. 59-67.

Krippendorff Klaus (1989) On the Essential Contexts of Artifacts or on the Proposition That ”Design Is Making Sense (of Things)", Design Issues, vol. 5, n. 2, pp. 9-39. http://dx.doi.org/10.2307/1511512

Magretta Joan (2002) Why Business Models Matter, Harvard Business Review, May, vol. 80, n. 5, pp. 86-92.

Manzini Ezio, Vezzoli Carlo (2003) A Strategic Design Approach to Develop Sustainable Product Service Systems: Examples Taken from the 'Environmentally Friendly Innovation' Italian Prize, Journal of Cleaner Production, vol. 11, n. 8, pp. 851-857. http://dx.doi.org/10.1016/S0959-6526(02)00153-1

March James G. (1991) Exploration and Exploitation in Organizational Learning, Organization Science, vol. 2, n. 1, pp. 71-87. http://dx.doi.org/10.1287/orsc.2.1.71

Markides Costantinos (2006) Disruptive Innovation: in Need of Better Theory, Journal of Product Innovation Management, vol. 23, n. 1, pp. 19-25. http://dx.doi.org/10.1111/j.1540-5885.2005.00177.x

Martin Roger L. (2009) The Design of Business: Why Design Thinking Is the Next Competitive Advantage, Harvard Business Press, Boston,

McKelvey Maureen (2001) The Economic Dynamics Of Software: Three Competing Business Models Exemplified Through Microsoft, Netscape And Linux, Economics of Innovation and New Technology, vol. 10, n. 2-3, pp. 199-236. http://dx.doi.org/10.1080/10438590100000009

Mintzberg Henry (1979) The Structuring of Organizations, Prentice-Hall, Englewood Cliffs.

Mohanbir Sawhney, Verona Gianmario, Prandelli Emanuela (2005) Collaborating to Create: The Internet as a Platform for Customer Engagement in Product Innovation, Journal of interactive marketing, vol. 19, n. 4, pp. 4-17. http://dx.doi.org/10.1002/dir.20046

Morelli Nicola (2002) Designing Product/Service Systems: A Methodological Exploration, Design Issues, vol. 18, n. 3, pp. 3-17.

Morris Michael, Schindehutte Minet, Allen Jeffrey (2005) The Entrepreneur's Business Model: toward a Unified Perspective, Journal of Business Research, vol. 58, n. 6, pp. 726-735. http://dx.doi.org/10.1016/i.jbusres.2003.11.001

Noble Charles H., Kumar Minu (2010) Exploring the Appeal of Product Design: A Grounded, Value-Based Model of Key Design Elements and Relationships, Journal of Product Innovation Management, vol. 27, n. 5, pp. 640-657. http://dx.doi.org/10.1111/j.1540-5885.2010.00742.x

Norman Donald A. (2005) Emotional Design: Why We Love (or Hate) Everyday Things, Basic Books, New York.

Osterwalder Alexander, Pigneur Yves (2010) Business Model Generation: A Handbook for Visionaries, Game Changers, and Challengers, Wiley, Hoboken.

Osterwalder Alexander, Pigneur Yves, Tucci Christopher L. (2005) Clarifying Business Models: Origins, Present, and Future of the Concept, Communications of the Association for Information Systems, vol. 16, pp. 1-25. 
Person Oscar, Schoormans Jan, Snelders Dirk (2008) Should New Products Look Similar or Different? The Influence of the Market Environment on Strategic Product Styling, Design Studies, vol. 29, n. 1, pp. 30-48. http://dx.doi.org/10.1016/j.destud.2007.06.005

Pisano Gary P., Verganti Roberto (2008) Which Kind of Collaboration is Right for You? Harvard Business Review, vol. 86, n. 4, pp. 78-86.

Ravasi Davide, Lojacono Gabriella (2005) Managing Design and Designers for Strategic Renewal, Long range planning, vol. 38, n. 1, pp. 51-77. http://dx.doi.org/10.1016/j.lrp.2004.11.010

Ravasi Davide, Stigliani Ileana (2012) Product Design: A Review and Research Agenda for Management Studies, International Journal of Management Reviews, vol. 14, n. 4, pp. 464-488. http://dx.doi.org/10.1111/j.1468-2370.2012.00330.x

Ravasi Davide, Rindova Violina, Dalpiaz Elena (2012) The Cultural Side of Value Creation, Strategic Organization, vol. 10, n. 3, pp. 231-239. http://dx.doi.org/10.1177/1476127012452824

Searls Doc (2009) The Cluetrain Manifesto, Basic Books, New York.

Shneiderman Ben (2007) Creativity Support Tools: Accelerating Discovery and Innovation, Communications of the ACM, vol. 50, n. 12, pp. 20-32. http://dx.doi.org/10.1145/1323688.1323689

Teece David J. (2009) Business Models, Business Strategy and Innovation, Long Range Planning, vol. 43, n. 2-3, pp. 172-194. http://dx.doi.org/10.1016/j.lrp.2009.07.003

Timmers Paul (1998) Business Models for Electronic Markets, Electronic Markets, vol. 8, n. 2, pp. 3-8. http://dx.doi.org/10.1080/10196789800000016

Verganti Roberto (2009) Design-Driven Innovation: Changing the Rules of Competition by Radically Innovating What Things Mean, Harvard Business Press, Boston.

Verganti Roberto (2008) Design, Meanings, and Radical Innovation: A Metamodel and a Research Agenda, Journal of Product Innovation Management, vol. 25, n. 5, pp. 436-456. http://dx.doi.org/10.1111/j.1540-5885.2008.00313.x

Verganti Roberto (2006) Innovating Through Design, Harvard Business Review, vol. 84, pp. 114122.

Verganti Roberto (2003) Design as Brokering of Languages: Innovation Strategies in Italian Firms, Design Management Journal (Former Series), vol. 14, n. 3, pp. 34-42. http://dx.doi.org/10.1111/j.1948-7169.2003.tb00050.x

Voelpel Sven C., Leibold Marius, Streb Christoph K. (2005) The Innovation Meme: Managing Innovation Replicators for Organizational Fitness, Journal of Change Management, vol. 5, n. 1, pp. 57-69. http://dx.doi.org/10.1080/14697010500036338

Von Hippel Eric (2005) Democratizing Innovation, MIT Press.

Weill Peter, Vitale Michael R. (2001) Place to Space: Migrating to e-Business Models. Boston, MA: Harvard Business School Press.

Yin Robert K. (1981) The Case Study as a Serious Research Strategy, Science Communication, vol. 3, n. 1, pp. 97-114. http://dx.doi.org/10.1177/107554708100300106

Yin Robert K. (1984) Case Study Research: Design and Methods, Sage, Thousand Oaks.

Zott Christoph, Amit Raphael (2008) The Fit between Product Market Strategy and Business Model: Implications for Firm Performance, Strategic Management Journal, vol. 29, n. 1, pp. 1-26. http://dx.doi.org/10.1002/smj.642 